\title{
A "seção romana" da Alexandra, de Lícofron (vv. 1226-1282) $)^{1}$
}

Rafael Brunhara

"No imo firme persegue enigmas desditosos

Desenreda as veredas qual sabida trilha, Guia através das trevas a estrada correta".

Lícofron, Alexandra, vv. 10-12

Resumo: A "seção romana" do poema Alexandra, de Licofron, é uma passagem de 56 versos em que a profetiza prevê um futuro grandioso para os descendentes e, ao contrário, um funesto porvir aos próprios aqueus. A passagem é tão conveniente à prespectiva da Eneida, que há quem creia tratar-se de imterpolação, entre outros motivos pelo fato de ser a primeira intersecção entre o mito de Eneias e o de Rômulo e Remo. A tradução dos trímetros jâmbicos foi feita em dodecassilabos acentuados na sexta silaba, mantendo-se anacolutos, hipérbatos, cavalgamentos, que produrem a já notória estranheza da sintaxe do poema. Procuro manter por compensação as recorrências sonoras e a logopeia. Palavras-Chave: Licofron, Alexandra; "seção romana"; tradução poética; poesia pré-belenística.

\section{Introdução}

A $S u d a^{2}$, enciclopédia do período bizantino, diz a respeito do poeta helenístico Lícofron:

1 Agradeço a João Angelo Oliva Neto pela sugestão de traduzir a passagem, e a José Carlos Baracat Júnior, Leonardo Antunes e Tadeu Andrade, por comentarem versões prévias deste artigo.

2 Edição de Adler, III; Berlin: Teubner (1933). 


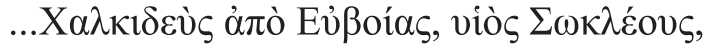

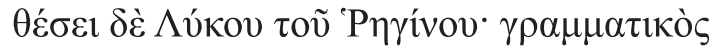

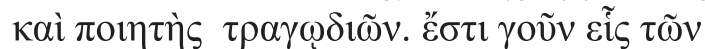

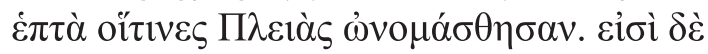

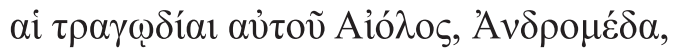

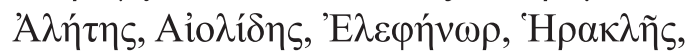

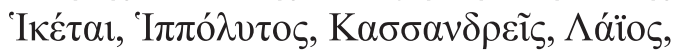

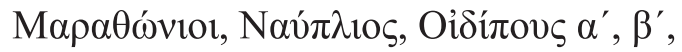

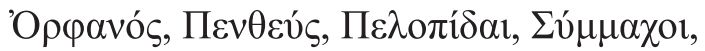

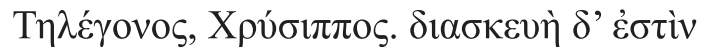

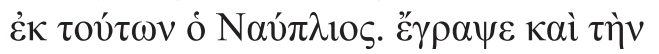

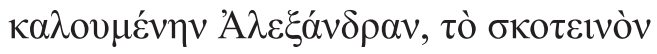
$\pi$ oín $\mu \alpha$.
... Natural de Cálcis, na Eubeia, filho de Sócles, mas, por adoção, de Lico de Régio. Gramático e poeta trágico. É, assim, um dos sete poetas que foram denominados como a "Plêiade". São suas as tragédias Éolo, Andrômeda, Aletes, Eólida, Elefênor, Héracles, Suplicantes, Hipólito, Os filhos de Cassandra, Laio, Maratônios, Náuplio, Édipo I e II, Órfão, Penteu, Pelópidas, Aliados, Telêgono, Crisipo. Dessas, Náuplio é uma versão reelaborada. Compôs também a assim chamada Alexandra, o poema obscuro.

Das peças acima elencadas, só nos restaram os títulos e apenas um fragmento. Sua única obra integral supérstite é justamente a Alexandra, aquela que a Suda registra como "o poema obscuro" (tò skoteinòn poíema), refletindo uma opinião já compartilhada na Antiguidade por autores como Luciano de Samósata ${ }^{3}$ e Estácio 4 .

A obscuridade se deve, sobretudo, ao estilo empregado pelo poeta, pautado pela sintaxe difícil, emprego de adjetivos e epítetos pouco habituais para se referir a personagens da tradição mítica e muitos vocábulos raros, que ocorrem no poema pela primeira ou única vez e frequentemente com sentido pouco usual. Não é admirável que a conjunção de todos esses elementos tornasse a Alexandra um poema difícil mesmo para os seus contemporâneos.

O poema é um extenso monólogo composto em 1474 trímetros jâmbicos, no qual um mensageiro informa ao rei Príamo as profecias de Alexandra (isto é, Cassandra, sacerdotisa de Apolo, filha de Príamo). Na primeira parte, logo após o prólogo do mensageiro (vv. 1-30), a profecia versa sobre a destruição de Troia e destino ulterior dos chefes gregos e troianos sobreviventes (vv. 31-1282). Em seguida, o poema expande-se na segunda parte, que apresenta uma história mais ou menos linear dos conflitos entre Oriente e Ocidente (vv.1283-1460), até concluir com uma fala do mensageiro (vv. 1461-1474) como que emoldurando o discurso de Cassandra.

3 Lexiphanes 25: "E quanto à tua prosa, poderíamos compará-la a versos como os do "Altar" de Dosíadas, ou da Alexandra de Lícofron, ou a expressões ainda mais infelizes do que essas, se é que existem". Dosíadas de Creta é autor de um dos cinco poemas figurados da Antologia Palatina (15.26): a disposição dos versos imita a figura do objeto (no caso, um altar) do qual os próprios versos enigmaticamente tratam: são obscuros porque procuram desafiar quem os ouve a adivinhar qual é a figura, ao passo que quem os lê e os vê tem a solução do enigma.

4 Silvae, 5.3.157: latebras Lycophroni atri, "recessos do escuro Lícofron”. 
É interessante notar que ambas as partes da profecia se encerram com alusões a futuras conquistas empreendidas pelos romanos, alusões essas que têm perturbado uma série de estudiosos quanto à datação do poema ${ }^{5}$ ou da autoria das passagens em questão. Oferecemos aqui uma proposta de tradução para um desses trechos, os versos 1226-1282.

\section{Critérios da tradução}

Lícofron utiliza no poema o trímetro jâmbico, metro típico na tragédia, com um rigor notável: seus versos pouco recorrem à chamada "resolução", isto é, a troca de uma sílaba longa por duas breves, e raramente ultrapassam doze sílabas. Optamos por traduzir a passagem em versos dodecassílabos sempre com acento na sexta sílaba, na tentativa de imitar em língua portuguesa a mesma rigidez que o poeta demonstra em língua grega.

Não buscamos amenizar a estranheza sintática do original, propiciada por anacolutos, hipérbatos, cavalgamentos e pelo alongamento da frase por meio do acréscimo de orações relativas, participais ou apositivas, que prejudicam a linearidade da sentença.

Julgamos também fundamental manter alguns efeitos e jogos de palavra empreendidos pelo poeta. Vale citar como exemplo a passagem na qual Lícofron parece se referir obliquamente a Roma (vv.1233-1234), utilizando a palavra grega 

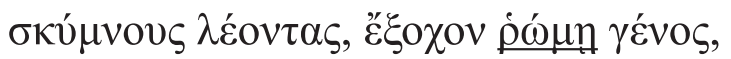

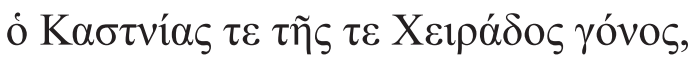

que em tradução literal poderíamos verter como:

leões filhotes, raça proeminente pela força física [rhômę],

a prole de Cástnia, a Quírade

Tentei manter a alusão, porém mediante recurso gráfico, traduzindo a passagem da seguinte maneira:

5 Ver, por exemplo, West (1984), Erskine (2003) e Lambin (2005). 
leões filhotes, ramo de preclaRO MAndo, de Quírade, a Cástnia, prole pujante

Da passagem acima também podemos notar outro expediente comum ${ }^{6}$ na Alexandra: no final do verso 1234, a palavra yóvos (gónos, "prole") ecoa a sonoridade de $\gamma \varepsilon ́$ vo (génos, "raça"), do verso anterior. Tentamos manter o jogo sonoro por meio da repetição das consoantes pr em mesma posição métrica: "preclaro" no verso 1233; "prole" no verso 1234.

O uso de vocabulário solene ou pouco conhecido também é marca singular do poeta, que tentamos seguir sempre que possível. Cabe aqui o exemplo notável do verso 1280, referindo-se à habitação da Sibila:

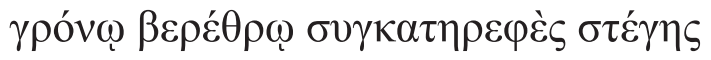

(grónoi beréthroi synkaterephiès stéges)

...por báratros

Cavernosos do teto muito recoberta.

O verso demonstra exemplarmente toda a densidade e vigor vocabular do poeta helenístico. Para descrever a caverna da Sibila, Lícofron utiliza apenas quatro vocábulos, todos eles raros: $\gamma \rho o ́ v \omega$ (grónoı), palavra que significa "cavernoso", "recesso", e ocorre somente em Lícofron com essa grafia (a mais comum é $\gamma \rho \tilde{\omega} v o \zeta$,

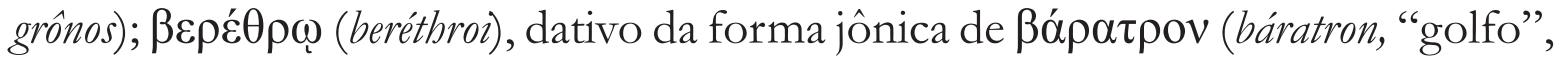

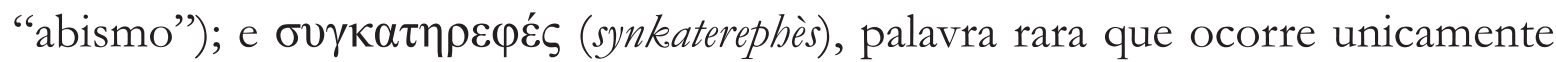
neste verso em toda a literatura grega supérstite.

\section{A “seção romana"}

Caso se tome como certa a hipótese de que a passagem aqui traduzida fora composta por um poeta chamado Lícofron, atuante na época de Ptolomeu Filadelfo (285-247 a.C.), o que ainda é objeto de debate ${ }^{7}$, teremos um dos momentos mais surpreendentes de todo o poema, que pode também lançar luz na

6 Ver, por exemplo, vv. 419-420, que faz um jogo de palavras entre $\pi \varepsilon ́ \lambda \alpha \varsigma$ (pélas, "perto") e $\lambda \dot{\pi} \pi \alpha \varsigma$ (lépas, "penhasco") de maneira similar ao exemplo exposto acima.

7 Erskine (2003) sugere a existência de dois poetas chamados Lícofron. West (1984) supõe que a seção romana seja interpolação. 
história da literatura latina, uma vez que nos é apresentada aqui, pela primeira vez, uma intersecção do mito de Eneias com o dos fundadores de Roma, os gêmeos

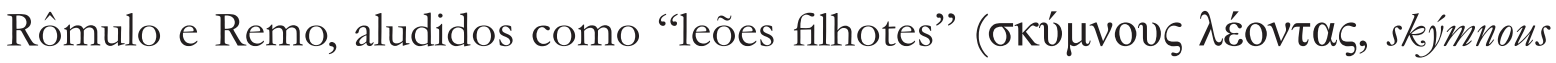
léontas, v. 1233).

A passagem se insere logo após o relato dos eventos que acontecerão a gregos e troianos após a guerra. Nele, Alexandra garante que o assentamento fundado por Eneias e seus descendentes na Itália será responsável por restaurar a glória perdida de Troia (vv. 1226-1231).

Em seguida, passa a relatar paragens visitadas pelo herói: primeiro, habitará a região do Recelo, na Macedônia (vv. 1236-1239), para em seguida partir para a Itália, às regiões margeadas pelo Tirreno e rio Lingeu (vv. 1239-1240), onde terá como aliados Odisseu, o "Anão" (vv. 1242-1244), e os filhos de Télefo, Tirreno e Tárcon (vv. 1242-1247). Ao chegar à Itália, verá realizada a primeira de suas profecias (vv. 1250-1252) ao encontrar a mesa repleta de alimentos, que será devorada por ele e os companheiros. Por causa dessa profecia, ocupará uma região antes habitada pelos primitivos povos do norte (vv. 1253-1254).

Depois, cumprindo outra profecia, que lhe instruíra contar as crias de uma porca negra que trazia desde Troia e erguer igual número de torres na região onde ela parira (vv. 1255-1258), erguerá trinta cidades, das quais a principal é Lavínio, onde erguerá de bronze uma estátua da porca e da cria (vv. 1259-1260).

Antes, porém, fundará um templo para Atena e lá dedicará as efígies dos Penates (vv. 1261-1262), que envolvera no manto durante a tomada de Troia pelos gregos e que lhe foram mais importantes que a esposa, filhos e todas as riquezas (vv. 1263-1267). Esse fato o fez ser considerado o mais pio até mesmo pelos inimigos, que lhe deram a oportunidade de pegar um único bem e levá-lo de seu palácio (vv. 1268-1271).

Graças a Eneias, será fundada a nação romana, limitada pelo monte Circeu, o ancoradouro de Eetes, o Lago de Fórcis, a fonte Titônia e a região onde vive a abominável Sibila, consagrada a Apolo, o Zostério (vv. 1279-1280).

A seção romana termina com uma imprecação de Cassandra (vv. 1281-1282), que, embora pareça conclusão inapropriada para os versos anteriores, encerra não somente a seção, mas também toda a narrativa que descreve o retorno malogrado e as aflições dos aqueus após a guerra de Troia (vv. 361-1089; 1090-1125 e 1214-1225).

Segundo McNellis e Sens (2011, p. 80), talvez a passagem tenha servido de lente, ou de principal modelo, para a interpretação que Virgílio deu aos versos 302308 da Ilíada, que já asseguravam a continuação da descendência de Eneias como rei de Troia e pai de uma linhagem que continuaria indefinidamente no tempo. 


\section{Texto da "seção romana" (vv. 1226-1282) da Alexandra, de Lícofron}

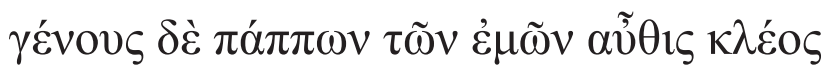

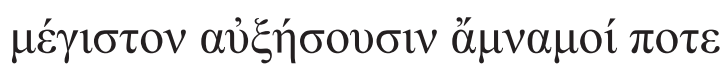

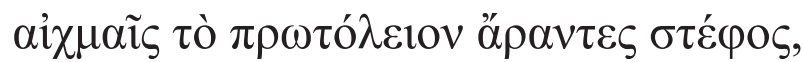

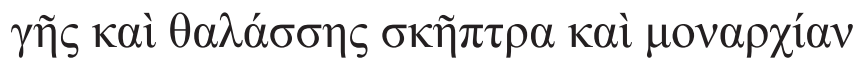

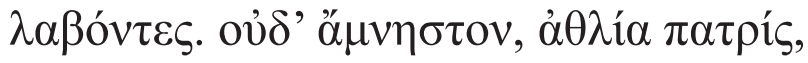

1230

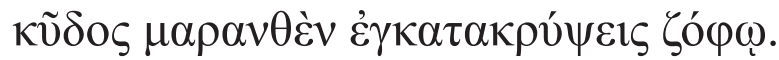

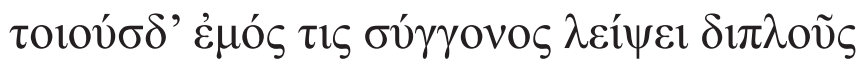

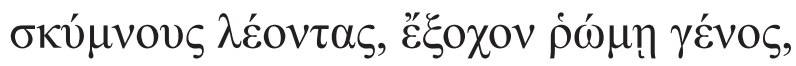

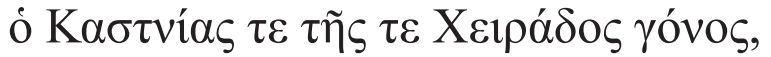

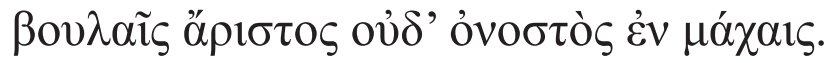

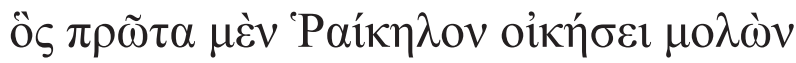

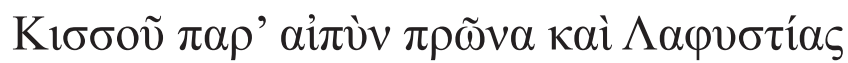

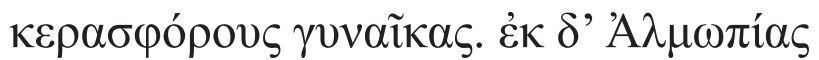

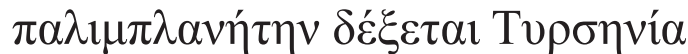

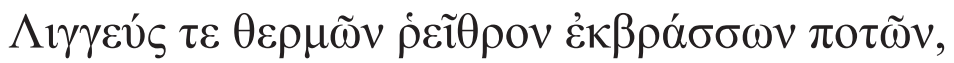

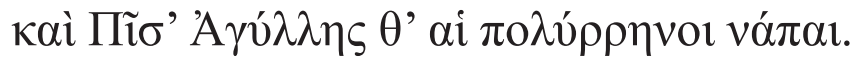

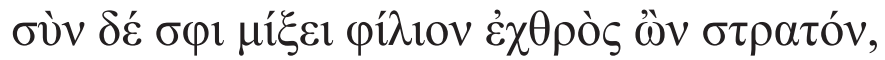

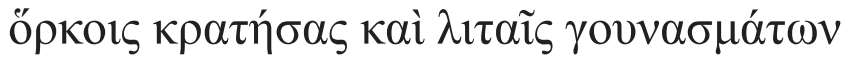

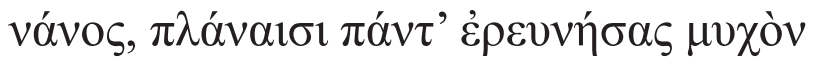

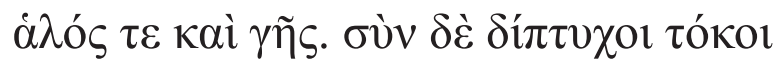

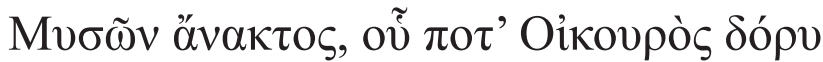

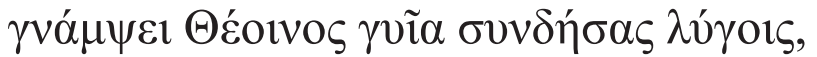

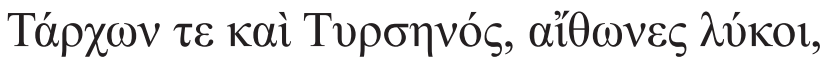

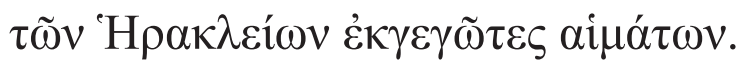

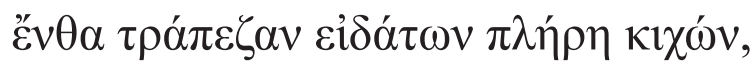

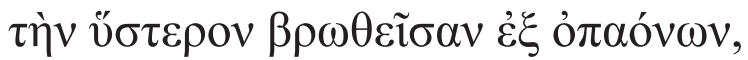

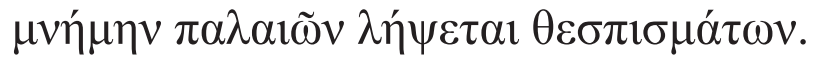

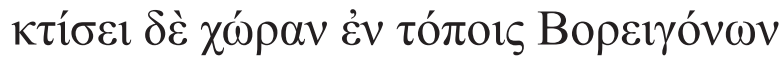

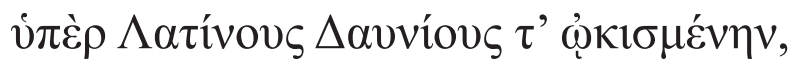

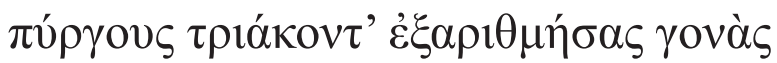




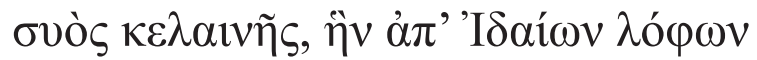

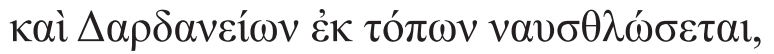

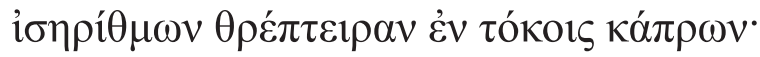

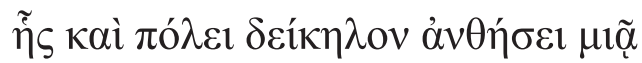

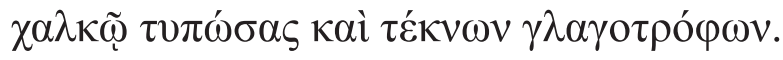

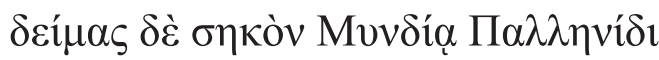

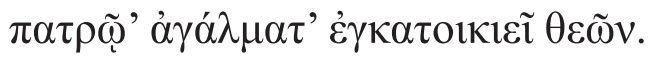

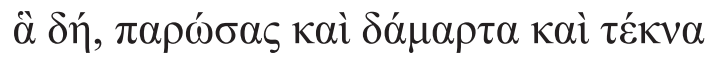

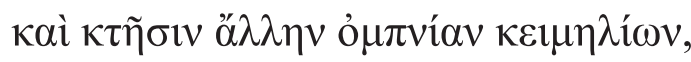

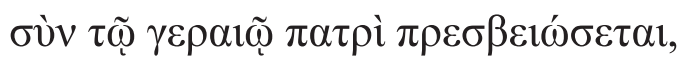

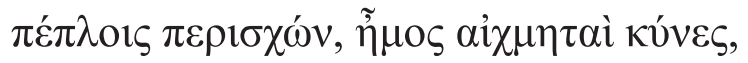

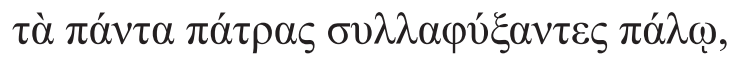

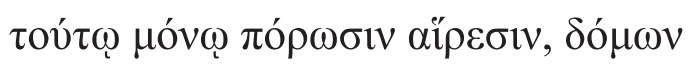

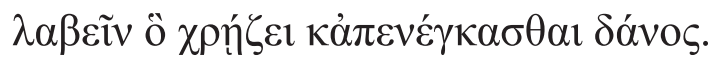

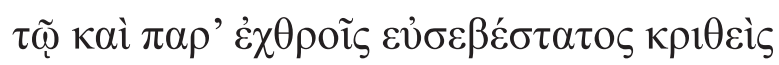

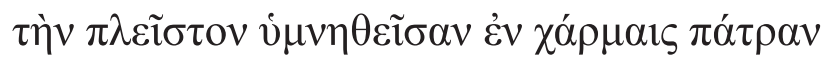

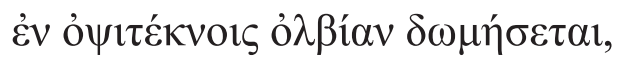

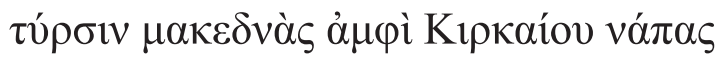

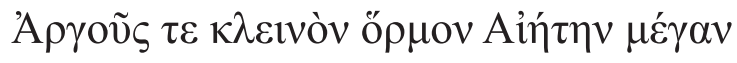

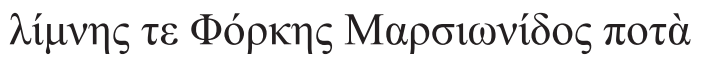

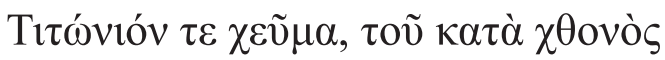

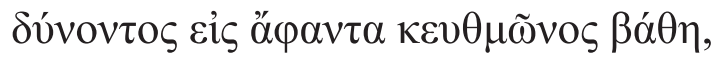

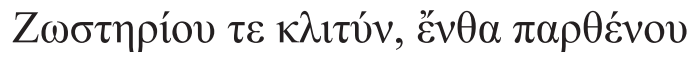

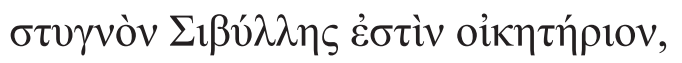

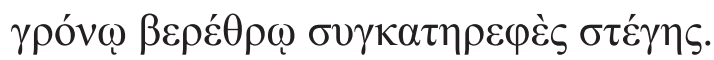

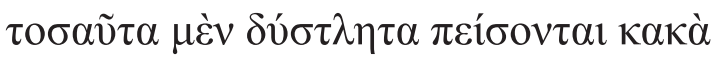

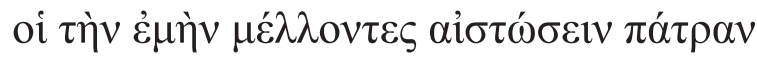

\section{Tradução ${ }^{8}$ da "seção romana" (vv. 1226-1282) da Alexandra, de Lícofron}

E então dos meus avós o renome da raça um dia os descendentes alçarão ao máximo; nas lanças levarão lauréis - suas primícias,

8 A tradução segue a edição de A. W. Mair (1921). 
e da terra e do mar, cetro e supremacia tomarão. Triste pátria, deslembrada e extinta,

tu não encobrirás tua glória nas trevas!

Tal dupla deixará um conterrâneo meu',

leões filhotes ${ }^{10}$, ramo de preclaro mando,

de Quírade ${ }^{11}$, a Cástnia ${ }^{12}$, prole pujante

em conselho o melhor e não vil em combate.

Primeiro ele virá a habitar o Recelo ${ }^{13}$,

perto do promontório íngreme de Cisso

e cornígeras fêmeas Lafístias ${ }^{14}$; depois,

desde Almópia ${ }^{15}$ vagando o acolherão Tirreno

e Lingeu ${ }^{16}$, rio que lança cálidas poções,

9 Refere-se a Eneias, filho de Anquises, que por sua vez é bisneto de Trôs, o herói epônimo de Troia. Príamo, pai de Cassandra, é também bisneto de Trôs, o que faria de Eneias e Cassandra primos distantes; ver Apolodoro, Biblioteca, 3. 12.2 ss.

10 Rômulo e Remo.

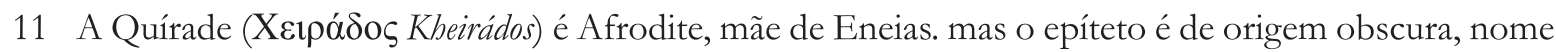

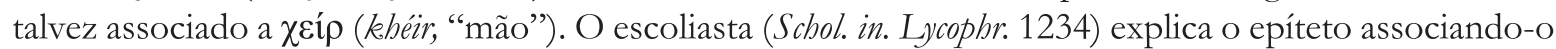
ao verbo $\chi \varepsilon 1 \rho o ́ \omega$ (cheiróo, "dominar"): segundo ele, Afrodite é "Quírade" por ser a deusa que "domina por

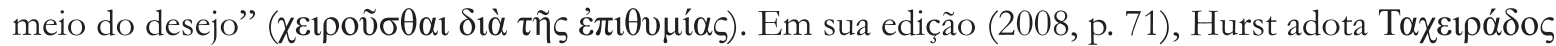

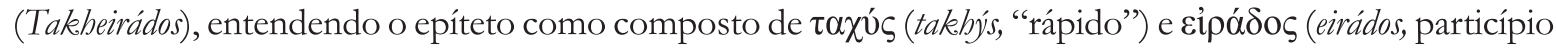
do verbo cíp $\omega$, éiro, "entrelaçar"), do qual uma tradução possível seria "a de rápido enlace".

12 Cástnia porque Afrodite era venerada no monte Cástnion, região perto de Aspendo, colônia da Argólida,

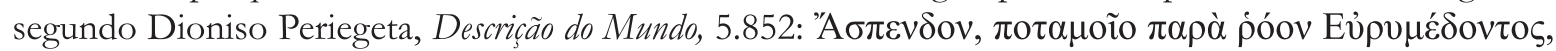

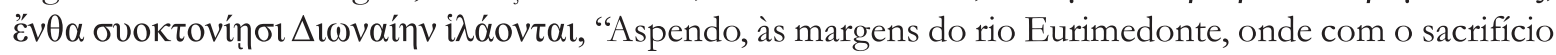
de porcos se propicia a filha de Dione".

Calímaco também chama a deusa por este epíteto em um dos fragmentos jâmbicos (200a 1-2 Pfeiffer):

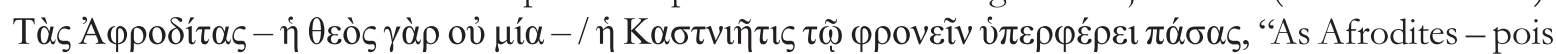
não é uma só a Deusa - / a Cástnia que no pensar excele a todas".

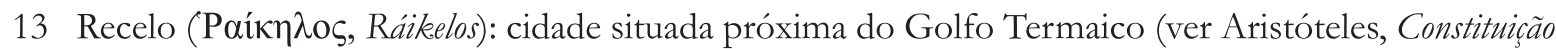
dos Atenienses, 15.2.3) ou do Golfo Salônico, na Macedônia, ao norte da península calcídica.

14 Na região do monte Cisso prestava-se culto a Dioniso. Lafístias pode se referir ao monte Lafístio, na Beócia, mas também a um epíteto de Dioniso. As sacerdotisas de Dioniso aqui referidas compartilham com seu deus patrono tanto o epíteto, que poderia ser traduzido por "Voraz" ou "Devorador", como o adjetivo "Cornígero", uma vez que Dioniso é o Deus de chifres.

15 Novamente referindo-se à Macedônia.

16 O rio Lingeu, Lígure, ou como é mais conhecido, Arno. A lição $\lambda ı \gamma \gamma \varepsilon u ́ \varsigma$ (lingéus), que adotamos para

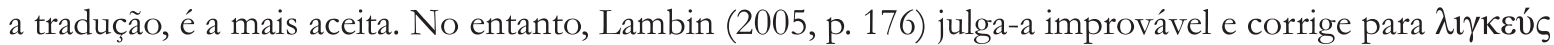
(linkéus), homônimo do herói que participa da expedição dos Argonautas. Acerca das águas quentes deste rio, ver Plínio, o Velho, História Natural, 2.227. 
e Pisa e vales ricos em rebanhos de Ágila ${ }^{17}$.

A ele unirá tropa amiga o antes hostil,

pós vencê-lo com juras e preces e súplicas,

o Anão ${ }^{18}$, que cada canto em errância explorou

do salso mar e terra, e também os dois filhos

do rei dos Mísios $^{19}$ - cuja lança um dia o Vígil ${ }^{20}$

Vinho-Deus dobrará, membros presos com vime ${ }^{21}$,-

árdegos lobos Tárcon ${ }^{22}$ e Tirreno ${ }^{23}$, natos

do sangue de Heraclidas ${ }^{24}$. Lá ${ }^{25}$ encontrarão

repleta de alimentos a mesa, que logo

devorada por seus companheiros trará

lembrança de proféticas palavras prístinas ${ }^{26}$ :

17 Pisa e Ágila são cidades na região da Itália. Os agilenses já são mencionados por Heródoto, Histórias, 1.167.

18 O Anão é provavelmente Odisseu (talvez uma referência à sua baixa estatura, já mencionada na Ilíada, 3.193), que antes fora hostil a Eneias em Troia, mas agora une seu exército ao dele. Lícofron parece pautar-se aqui em uma versão alternativa em que Odisseu está junto de Eneias na fundação de Roma. A versão é referida por Dionísio de Halicarnasso, Antiguidades Romanas, 1.72, mas é também mencionada em fragmentos da obra Sacerdotisas de Hera em Argos, de Helânico de Lesbos (FGRHist 4 F 84 Jacoby) e ratificada pelo historiógrafo Damastes de Sigeu (FGRHist 5 F 3). Para detalhes, ver Solmsen, 1986, p. 93-110. No entanto, ao chamar Odisseu de "anão" (vóvos, nános), Lícofron faz um jogo de palavras que evoca além de Odisseu, a figura do herói Nano, rei mítico dos Pelasgos (ver Heródoto, Histórias, 1.57), que teria liderado a incursão de seu povo na região do Tirreno e cuja lenda havia se assimilado a de Odisseu (ver Lambin, 2005, p. 179).

19 Télefo era o rei dos Mísios.

20 Oíkoupós (oikourós), epíteto de Dioniso: "Guardião da casa", i.é, "Vígil”.

21 Quando os gregos, em meio à sua expedição para Troia, se aproximaram da Mísia, Télefo os enfrentou e quase os teria repelido, se Dioniso não tivesse auxiliado os gregos, prendendo os pés do rei mísio com vinha e deixando-o vulnerável ao ataque de Aquiles; ver Píndaro, Ístmica, 8.48-50.

22 Sobre Tárcon, ver Virgílio, Eneida, 8.503-505 e 8.603-607. Segundo Estrabão (Geografia, 5.2) é o herói fundador da cidade de Tarquínia.

23 Herói epônimo dos Tirrênios, i.é, dos etruscos.

24 Télefo é filho de Héracles; por isso, Tárcon e Tirreno, seus filhos, são "natos de sangue dos Heraclidas".

25 Na Itália.

26 Virgílio, Eneida, 3.250-257, traz a profecia, contada por uma Harpia: "Ouvi, então, o que tenho a dizer-vos, sem nada ocultar-vos. / Tudo o que Apolo aprendeu com o mais forte dos deuses, e logo / me revelou, eu, das Fúrias a mais poderosa, vos conto. / Vossos anseios à Itália vos levam. Com prósperos ventos/ heis de alcançar por sem dúvida a Itália e adentrar os seus portos. / Mas, antes mesmo de vossa cidade querida dos deuses / de altos muros cingirdes, haveis de sofrer dura fome / por este crime: forçados sereis a roer até as mesas", recordada por Eneias em 7.122-127: "Eis nossa pátria, a morada. Meu 
fundará um país na terra dos Borígonos ${ }^{27}$

situado p'ra além dos Latinos e Dâunios ${ }^{28}$

e trinta torres ${ }^{29}$, pós contar de negra sus ${ }^{30}$

a prole; no navio ele a conduzirá

desde cimos do Ida e das terras dardânias,

nutriz de equivalentes javalis filhotes;

consagrará em uma só cidade ${ }^{31}$ imagem

brônzea dela e também de sua prole lactente

depois de erguer um templo p'ra Míndia Palênide ${ }^{32}$

assentará efígies de seus deuses pátrios,

sim, por eles deixou esposa e filhos, mais

as suas ricas posses, para venerá-los

com o pai ancião, envolvendo-os em mantos

no momento em que os cães lanceiros ${ }^{33}$ no sorteio

devoram os bens todos da pátria. Somente

para ele deram esta escolha: de seu paço

pegar o que quiser e levar como dádiva ${ }^{34}$;

pai - neste instante me lembra - / me revelou os arcanos do incerto Destino, faz tempo:/ 'Quando, meu filho, jogado em paragens ignotas de todos, / já consumidos os parcos manjares, te vires forçado / a devorar até as mesas... Então, sim: acharás um asilo / para esses membros; assenta o arraial, de trincheiras o cerca”. (Tradução de Carlos Alberto Nunes).

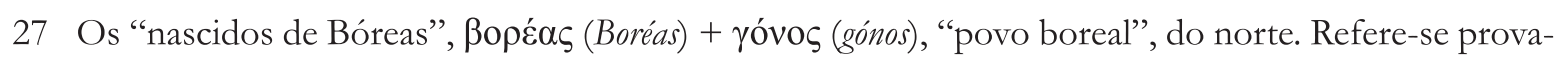
velmente aos Ligurinos, no norte da Itália.

28 Supõe-se que os dâunios fossem os samnitas.

29 Por "trinta torres" Lícofron alude às cidades do Lácio, assinaladas por Plínio, o Velho, História Natural, 3.69, da qual Lavínio é a principal.

30 "pós contar de negra sus/ a prole": trata-se de outra profecia da Eneida, 3.387-391: "Quando apreensivo estiveres nas margens de um rio sem nome, / e deparares deitada na sombra de bela azinheira / uma alva porca com trinta leitões ao seu lado, da mesma / cor da mãe branca, deitados no chão a mamar com sossego: / esse será o local da cidade, o descanso almejado"; (tradução de Carlos Alberto Nunes). Por motivos

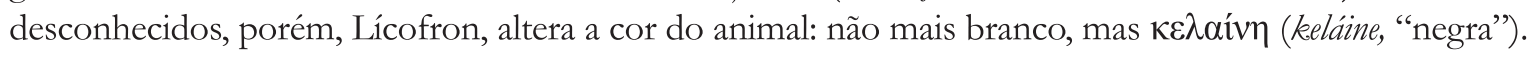

31 Lavínio.

32 "Míndia Palênide": trata-se de Atena, chamada "Míndia" também no v. 950. "Palênide" vem de Palene, nome de um demo entre Atenas e Maratona, onde Atena era cultuada; ver Heródoto, Histórias, 1.62.

33 Os gregos.

34 Dada a Eneias a oportunidade de levar do palácio apenas um de seus bens, o herói escolhe os Penates, envolvendo-os no manto. Por esse motivo, passa a ser considerado até pelos inimigos como o homem

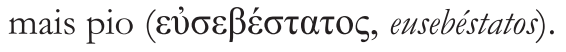


por isso até por seus inimigos julgado

o mais pio, venturosa pátria no ardor bélico

entre os pósteros mais hineada erguerá,

fortaleza cercada de elevados vales

de Circeu e Eetes ${ }^{35}$ - ínclito amplo ancoradouro

da Argo -, águas do lago de Marsênio Fórcis ${ }^{36}$,

e correntes Titônias ${ }^{37}$, que abaixo da terra

mergulham em abismos invisos, e costas

de Zostério $^{38}$, no ponto em que é da virginal

Sibila a abominável morada, por báratros

cavernosos do teto muito recoberta.

Que males sofrerão, difíceis de aguentar,

aqueles que estão para destruir-me a pátria!

\section{Referências}

ERSKINE, A. Troy between Greece and Rome: Local Tradition and Imperial Power. Oxford: Oxford University Press, 2003.

HURST, A. KOLDE, A. Lycophron, Alexandra, texte établi, traduit et annoté par A. H. en collaboration avec A. K. Paris: Les Belles Lettres, 2008.

LAMBIN, G. L'Alexandra de Lycophron, étude et traduction de Gérard Lambin. Rennes: Presses Universitaires de Rennes. 2005.

MAIR, A. W. Callimachus, Hymns and Epigram; Lycophron and Aratus. Cambridge (Massachussets): Harvard University Press, 1921.

MCNELIS, C. SENS, A. "Trojan Glory: Kleos and the Survival of Troy in Lycophron's Alexandra". In: Trends in Classics 3, 2011. pp. 54-82.

SOLMSEN, F. “Aeneas Founded Rome with Odysseus". In: Harvard Studies in Classical Philology 90, 1986. pp. 93-110.

35 O poeta relaciona lendas gregas à toponímia do Lácio: o monte Circeu associa-se à célebre feiticeira da Odisseia, ao passo que o nome do porto de Eetes ecoa o nome do rei da Cólquida, pai de Medeia.

36 O Lago Fórcis, homônimo da divindade marinha, talvez seja o mesmo lago mencionado por Estrabão

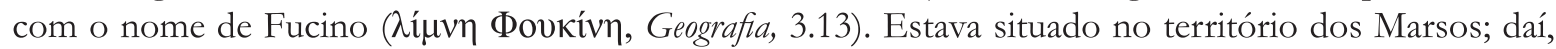
"Marsênio".

37 A fonte Titônia, ou Pitônia. Trata-se de uma fonte que surgia na terra dos Pelignos e parecia desaparecer em seu curso, "mergulhando em abismos invisos", para ser visível novamente na região de Tívoli.

38 O Zostério é Apolo, cultuado com esse nome no cabo Zóster, na Ática. 
VIRGÍLIO. Eneida, edição bilíngue, tradução de Carlos Alberto Nunes; organização, apresentação e notas de João Angelo Oliva Neto. São Paulo: Editora 34 (1a edição).

WEST, S. "Lycophron Italicised”. In: Journal of Hellenic Studies 104, 1986. pp. 127-151. 